\title{
Android Based Application Fawless (Food Assist Wasteless) As Innovative Solution On Reducing Food Waste
}

\author{
Putri Sekar Melati ${ }^{1}$, Sulistinayah Suwaka Putri ${ }^{2}$, Rossy Andini Herindra Putri ${ }^{3}$, \\ Lilit Rusyati ${ }^{4}$ \\ \{putrisekarmelatiimel@upi.edu\} \\ Department of Science Education, Faculty of Mathematics and Science Education, \\ Universitas Pendidikan Indonesia, Bandung, Indonesia ${ }^{1,2,3,4}$
}

\begin{abstract}
Food and Agriculture Organization of the United Nations (FAO) stated that one-third of global food production became food waste. Therefore, food waste issues become a worldwide concern that needs concrete and innovative solution combined with the latest technology. These facts are the reasons why FAWless (Food Assist Wasteless) is made. This android based application is made to reduce food waste that is produced by society by helping them by distributing their extra food or almost expired food so that it is not wasted. Besides, FAWless is also made to put food waste into use. This research uses the descriptive method. The samples are grouped into four categories which are student, student dormitory, household, and small and medium enterprise. The result shows that samples can install and use FAWless applications to distribute their extra food.
\end{abstract}

Keywords: Android-based application, FAWless, Food waste

\section{Introduction}

Human has been producing waste called kjokkenmoddinger or clamp shells since Mesolithic age [1]. But now, food waste is a big issue not only on the national scale but globally. Food waste is food that is wasted because of particular reasons even though the food is still eatable. There are a lot of food waste categories such as cereal, tubers, nuts, fruits, vegetables, meat, fish, etc. Food can be wasted on production, distribution or consumption that caused one-third of the food produced in the world is wasted [2]. Even Bandung produced $63,56 \%$ of food waste in a year [3].

This issue is getting worse with the increase in restaurants, café, or even the bad packaging [4]. Besides, the food produced is more than the food needed and the harvest process is not correctly done [2]. The consumer that overstocked food also increase food waste [5].

Food waste has a big impact on ecology, environment, poverty, and starvation. Food waste causes the changing of animal's behavior, diet, and habitat, it even increases diseases and bacteria [6]. Besides, it generates 3.3 gigatons of $\mathrm{CO}_{2}$ [4]. Related to poverty and starvation, food waste has worsened the case. Even now the world is facing a challenge to fulfill the food needs of 9 billion people [7]. 
A lot of solution has been proposed to reduce food waste. From buying less food, reusing, and recycling, using it as an energy source, to making last-minute market. Last Minute Market is a market that sells unsold fruits and vegetables that are eatable but going to be rotten soon [8]. Along with the industry revolution 4.0, the solutions proposed are integrated with technology such as informative, reminder, food sharing, planning, shopping list, food recipe, and Food Finder app [9]. Food Finder App is made to help the elderly to make a list of food stock so they will not but too much food [10].

Those are the reasons why FAWless (Food Assist Wasteless) is made. FAWless is an android-based app to reduce food waste that is produced by society by helping them to share their near expired food and beverages. Moreover, this app also made to put food waste into use. This app user is students, dormitory, household, and small and medium enterprises. When the user uses the app, FAWLess will pick the donation up and give it to the people in need. We hope FAWLess could be an innovative solution that urges people to reduce food waste.

\section{Method}

The type of research method chosen is descriptive analysis, the notion of a descriptive method of analysis according to (Sugiono: 2009; 29) is a method that serves to describe or give an overview of the objects examined through the data Or samples that have been collected as they are without conducting any analysis and making conclusions that apply to the public. In other words, analytical descriptive research is taking the problem or focusing attention on the problems as it is when the research is conducted, the results of the research that are then processed and analyzed to be taken in conclusion. In this case, the author took the problem of food waste, until then sought a solution in its response, by creating an application based Android FAWless (Food Assist Wasteless). This Android-based application is made to reduce the rest of the food produced in the environment by helping people channel excess food or food that is approaching expiration so that it is not wasted. So to research the role of Android-based application FAWless (Food Assist Wasteless) in student life, student dormitories, households, and small and medium enterprises. Authors use a descriptive method of analysis because it is deemed suitable to know the phenomenon that is currently ongoing.

The research subject is the primary data source as the informant as well as the FAWless application user (Food Assist Wasteless), to describe the role of the FAWless app (Food Assist Wasteless). The subject of research in this study is student, dorm, household, and small and medium enterprises. The subject determination of this study considers the association with food waste problems that are found in the life of the subject-research subjects above.

The object of this research is how the role of the Android-based application FAWless (Food Assist Wasteless) in student life, student dormitories, households, and small and medium enterprises. The object of research according to (Sugiyono: 2011) is called a social situation, consisting of three components of place or place where interaction in social situations is ongoing, actor or perpetrator/people who are playing a specific role, and Activity or activities undertaken by actors in ongoing social situations. The things discussed in this research include how the role of the Android-based application FAWless (Food Assist Wasteless) in student life, student dormitories, households, and small and medium enterprises. 


\subsection{Material}

In this research, FAWless is created using an application called "Juggle Jack". The first step of making FAWless application is, the author downloads the Juggle Jack app. Then, on the screen of the mobile phone, there is a view to creating the application, click "buat sekarang" as shown in Figure 1.a. After that, in Figure 1.b with the title "tambahkan aplikasi" click the icon and add the picture that we use. We set the name, code, categories, and description for the application. This app will be able to be seen after the author created and click the checkmark in the top right.
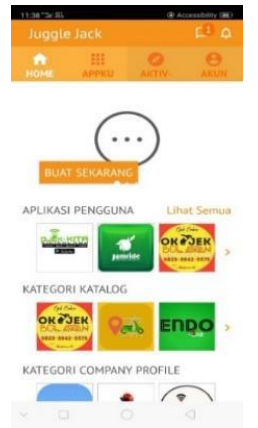

Fig.1.a Home screen of the juggle jack

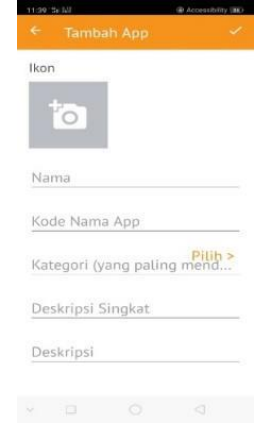

Fig.1.b Form to fill the application's description

In Figure 1.c there is the "Edit menu" to fill any tools that will appear on the screen of the mobile phone and in Figure 1.d there is a set of the base color. Figure 1.e that contains the description of the application and click the checkmark. Also in Figure 1.f "tutorial", to describe how to use the application then click the checkmark. Besides that, the author can also choose a suitable icon.

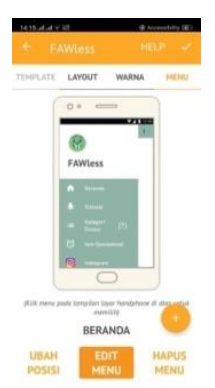

Fig.1.c Editing tools

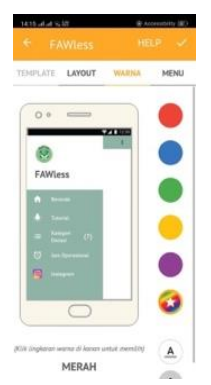

Fig.1.d Editing Colors

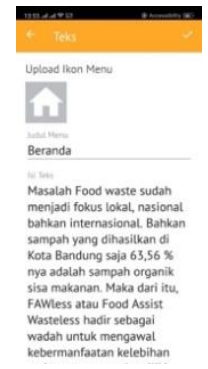

Fig.1.e Home feature

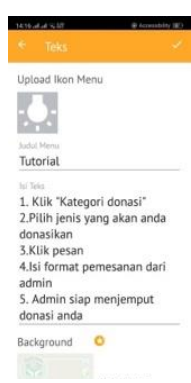

Fig.1.f Tutorials Feature

In Figure 1.g is the donation category, we can also add an image for each of its icons. In Figure 1.h this is operational time for FAWless's services. In Figure 1.i the next tool is Instagram. This is necessary for publishing the information through Instagram as the lastest social media. In Figure 1.j after the application is finished, then click the three dots in the upper right and click "Jadikan aplikasi". Figure 1.k Wait a few minutes, approximately 15-18 minutes and there will be a message from the Juggle Jack that the application is already done. 


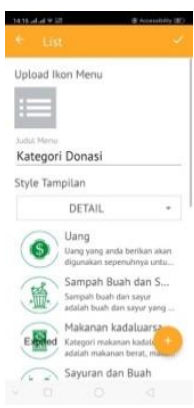

Fig.1.g. Donation Categories

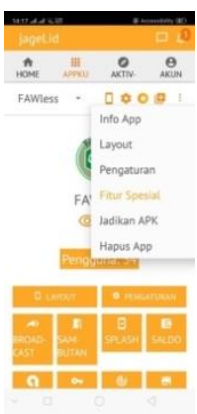

Fig.1.j Click"Jadikan APK"

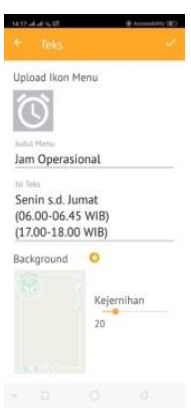

Fig.1.h Operational Time

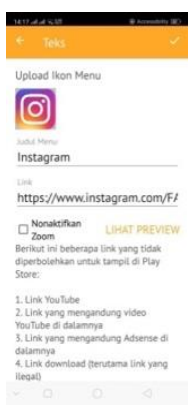

Fig.1.i Instagram feature

\author{
Aplikasimu sudah selesai dibuat. Silahkan \\ download di https://jgik.mobi/fawlessid \\ Silahkan kirim pesan seperti di bawah ini untuk \\ informasi lebih lanjut \\ /jadipremium \\ untuk informasi mengenai fitur premium \\ /uploadplaystore \\ untuk informasi memunculkan aplikasi di Play \\ Store \\ /gagalinstall \\ jika apk yang ada tidak bisa di Install
}

Fig.1.k Notification from Juggle Jack

\subsection{Experiment Stage}

To install and login This app is quite easy. First users simply download the FAWless app via the link which is provided by Juggle Jack, then register using the email address, as shown in Figure 2.a. when the user gets a message by email, and the user needs to verify the email. After verification, the user will automatically get the account and can use the FAWless application. After getting the account, users can see the FAWless application which has some features on the initial view of the application Figure 2.b such as home, tutorials, donation categories, operational time and Instagram. Each feature has different functions.

The Home feature Figure 2.c contains information about FAWless application so that the user can know the understanding of the application. Furthermore, there is a tutorial feature that discusses how to use and that users can access the application. To donate, select "category donation " Figure 2.d, there are seven categories that are provided by FAWless application is the meal, snack, beverages, fruit and vegetable, expired food, fruit, and vegetable waste. Users can choose the type of donation that will be discarded, then the user clicks the button "Pesan Jasa ", therefore the user can fill the form that has been provided. Users can donate and the donation will be taken according to the time that the user has specified Figure.2.e, then click the donation to be discarded, fill in the form that has been provided, such as date, hours, mobile phone number, payment type, location. Next click "Pesan Sekarang", then wait for confirmation from FAWless. The user can communicate with the admin or the officer who will distribute the donation through the in-app messaging feature. Wait, then FAWless team will take the donation. The FAWless administrator receives the message and immediately 
picked the user's donation that has been donated through FAWless. After FAWless classifies donations according to type from some users FAWless application, we will process or channel it to some activist community and the donate (people in need) for example, scavenger, beggar or orphanage. The user also can see the donation delivery at Instagram, as the latest social media. Figure 2.f on Instagram, there is information about the activity that will be in share periodically.

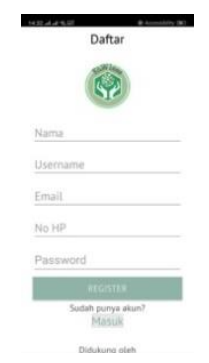

Fig.2.a Register the Username

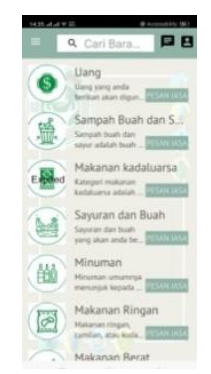

Fig.2.d List of Donation Categories

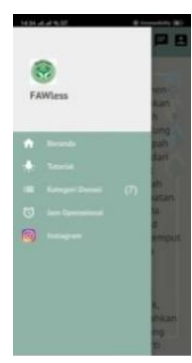

Fig.2.b Initial view of the app

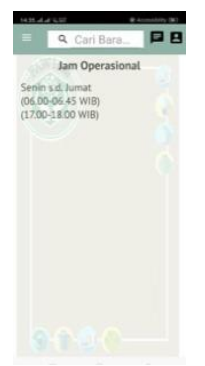

Fig.2.e Operational time view

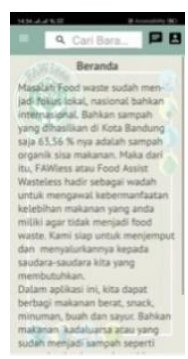

Fig.2.c Describe the Homepage

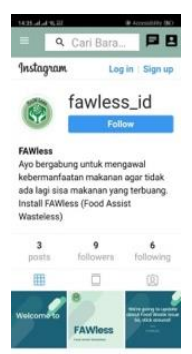

Fig.2.f Instagram View

\section{Result and Discussion}

The application can be downloaded by clicking the link which has been published (Figure 3.a. After successfully downloaded, it can be installed directly in the user's mobile phone and the user will receive a greeting message Figure 3.b. Users can donate based on the category in the application and the administrator will receive a direct message Figure 3.c. The administrator can see the donation by click "lihat pesanan" indirect message, and the specific information about the order will be shown in Figure 3.d and 3.e. Administration then pick the donation according to the time and place that the user has been specified Figure 3.f, 3.g, and 3.h. After FAWless collected the order from users, those will be categorized into the meal, snack, beverages, fruit and vegetable, expired food, fruit, and vegetable waste Figure 3.i. The users can also donate money through FAWless for operational costs. The donation will be distributed to people in need Figure 3.j, 3.k, and 3.l, and social community that develops compost, and also for money donation through FAWless for operational cost. 


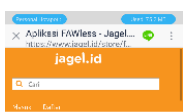

(62)

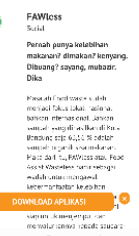

Fig.3.a Page for downloading the application

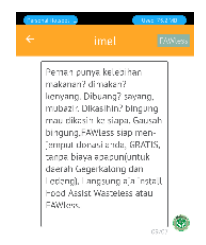

붐

Fig.3.b Greeting message from FAWless administrator

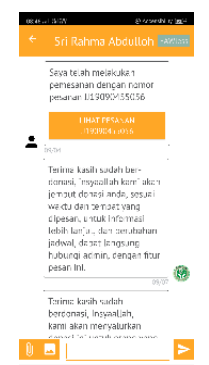

Fig.3.c Notification message from the user
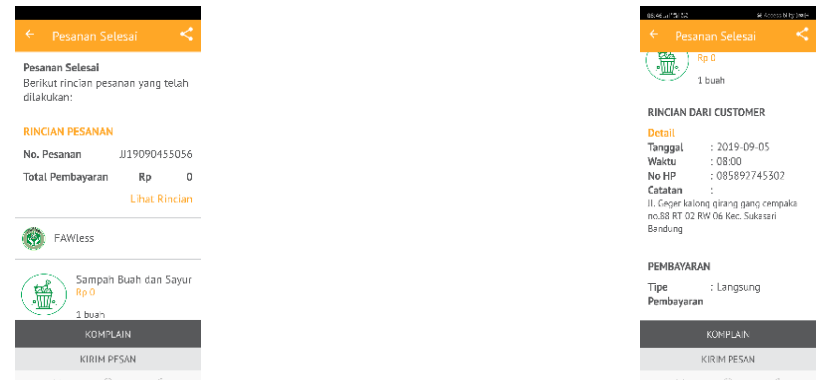

Fig.3.d and 3.e Specific information about the order

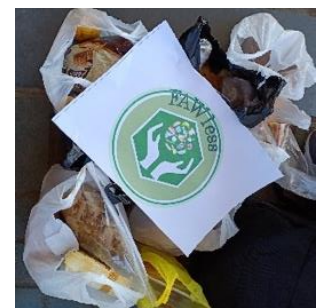

Fig.3. The donation has been categorized into the meal, snack, beverages, fruit and vegetable, expired food, fruit, and vegetable waste.
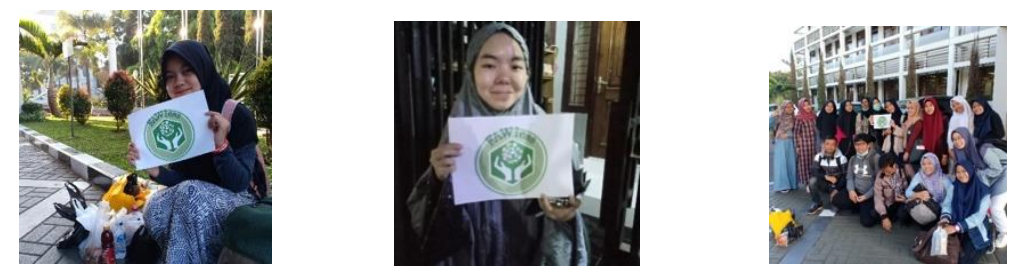

Fig.3.f, 3.g, and 3h. FAWless pick the order from users according to the time 

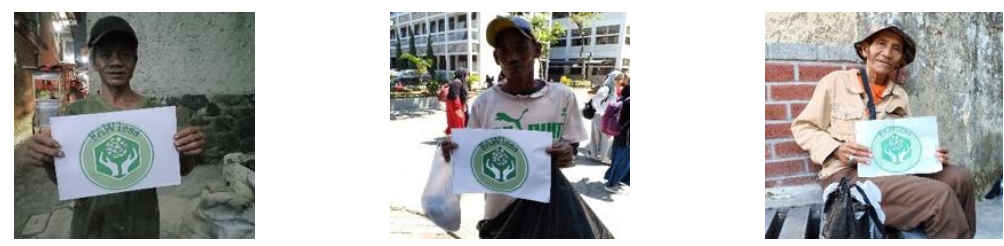

Fig 3.j, 3.k and 3.l. The food or donation will be distributed to people in need

Until September 10th2019, FAWless has 35 users Figure 3.m, and most of their domicile is in Bandung. According to our first statement that this application could be an innovative solution that urges people to reduce food waste. It is proven by our trial of FAWless on June 30th, 2019 until September 10th, 2019. Based on feedback from the user, FAWless can help them when they are confusing to find the place or someone who appropriate to receive their extra food. It also can help each other people, especially people in need. The author also receives feedback from many recipients of donations. FAWless can help them to have a meal, nutritious food, beverage or even fruit, that they rarely eat that food, because of lack of money.

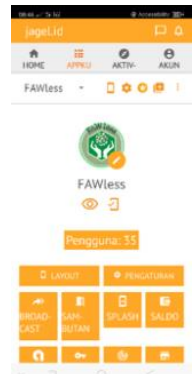

Fig.3.m FAWless's users, from June 30th, 2019 until September 10th, 2019.

Table 3.3 The donator of FAWless

\begin{tabular}{llll}
\hline No & Name & Type of donation & Date \\
\hline 1 & Nurfaida & Fruit and vegetable waste & June 28, 2019 \\
2 & Nola & Fruit and vegetable & September 06, 2019 \\
3 & Humaira & Fruit and vegetable & September 06, 2019 \\
4 & Haya Taira & Fruit and vegetable & September 05, 2019 \\
5 & Nimes Ayu L & Snack & September 06, 2019 \\
6 & Sausan & Food & September 06, 2019 \\
7 & Rahma Hanifa & Drink & September 06, 2019 \\
8 & Arnie & Snack & September 06, 2019 \\
9 & Ilfa Qurrota aini & Fruit and vegetable waste & September 06, 2019 \\
10 & Mira & Snack & September 06, 2019 \\
11 & Shofa nabilah & Snack & September 06, 2019 \\
12 & Mariah Syifa & Snack & September 06, 2019 \\
13 & Dea Puspha & Snack & September 05, 2019 \\
14 & Mutiara Balqis & Money & September 06, 2019 \\
15 & Dela Fitriani & Drink & September 06, 2019 \\
16 & Rizki Maulana & - & -
\end{tabular}




\begin{tabular}{llll}
17 & Hesti husnul & Snack & September 06, 2019 \\
18 & Surichairani & Snack & September 06, 2019 \\
19 & Falisha & Expired food & September 06, 2019 \\
20 & Rahma Hatma & Expired Food & September 06, 2019 \\
21 & Aisyah Nurul & Money & September 06, 2019 \\
22 & Fauzia Utami & Expired food & September 06, 2019 \\
23 & Zahara Faiziah & Drink & September 06, 2019 \\
\hline
\end{tabular}

The primary thing that can be improved according to this application is about language. To make FAWless broader, accessible, and more understandable, it can be used English or another language as language instruction. The author can even make it look more attractive, by adding some content in this application.

\section{Conclusion}

The paper shows that FAWless helps users to reduce food waste. The users successfully install the application and log in to it. FAWLess then receives the notification. The user is also able to access the chat feature in the application and make an appointment with FAWLess. FAWLess has received the donation from 33 users and distributes the donation to the people in need. All categories in the application have been tried by users. Even so, there are so many things that can be improved. In the future, FAWLess can be bigger than just an application. It can be a bigger social project. It might involve volunteers since the scope will be broader. FAWLess can also have shelters in the future so people know where to donate and where to ask for food.

\section{References}

[1]A. dkk Pradono.: Sejarah Indonesia, vol. 1, no. 11. (2015)

[2]I. Congress, Global f o o d losses a $\mathrm{n} d$ f o o d waste Global f o o d losses a n d f o o d waste

[3]G. Brigita, P. Studi, and T. Lingkungan.: "Food Waste Management Analysis in Bandung City," vol. d, no. April, pp. 34-45, (2013)

[4]M. C. Heller, S. E. M. Selke, and G. A. Keoleian.: "Mapping the Influence of Food Waste in Food Packaging Environmental Performance Assessments," J. Ind. Ecol., vol. 23, no. 2, pp. 480-495, (2019)

[5]J. Aschemann-Witzel, I. de Hooge, P. Amani, T. Bech-Larsen, and M. Oostindjer.: "Consumerrelated food waste: Causes and potential for action," Sustain., vol. 7, no. 6, pp. 6457-6477, (2015)

[6]T. M. Newsome and L. M. Van Eeden.: "The Effects of Food Waste on Wildlife and Humans," (2017)

[7]R. Rayfuse and N. Weisfelt.: "The Challenge of Food Security," vol. 327, no. February, pp. 812$819,(2012)$

[8]A. Segrè and S. Gaiani.: "Transforming food waste into a resource: European Resolution Against Food Waste and Its Impact/Consequences," World Water Week - SIWI-FAO, (2012)

[9]S. van der.: "ICT tools for food management and waste prevention at the consumer level," no. 641933, (2018)

[10]D. Pace,.: “Team : 'MunchAPP ' Coach : Dr . Jean Coppola Find the Food !,” (2016) 